\title{
Analysis of Important Steering Factors Which Give Success to Global Shipbuilding Leaders
}

\author{
Khandakar Akhter Hossain* \\ Chief Naval Architect and Marine Engineer, Wuchang Shipbuilding Industry Co Ltd, China
}

Submission: December 09, 2017; Published: April 10, 2018

*Corresponding author: Hossain A, Chief Naval Architect and Marine Engineer, BN Guided Missile Corvette Project, Wuchang Shipbuilding Industry Co Ltd, Wuhan, China, Tel: 0086-18251320510; Email: akhter.engineer@yahoo.com

\begin{abstract}
Shipbuilding is an important and strategic industry, because it has one of the highest multiplier effects among all other industries. Britain upto WW I, USA upto WW II, Japan after WW II, South Korea upto 2010 and China at present leading the global shipbuilding industry and enrich their other SMEs and backward linkage industries. The modern era of shipbuilding industry started its journey from the western countries. But due to the global impact as the cost of everything went up, the trend of shipbuilding industry was shifted from west to east. Thus the countries like China, Korea, Philippines and Vietnam are dominating the sectors. At present, the countries like Bangladesh, India, Indonesia, Turkey and Brazil are trying to hold the surplus market of shipbuilding industry, especially those demands that are not entertained by the traditional shipbuilding nations. Technical innovation and managerial skill always promote shipbuilding. During the process of the industrialization in the country, the shipbuilding industry developed due to huge internal demand for the ships as well. Financial support and involvement of government is the main driving force to grown up shipbuilding. It is an overview paper based on both primary and secondary information and extensive analysis of the fact and history of development of shipbuilding and design technology.
\end{abstract}

Keyword: Shipbuilding; Technology; Forward and backward linkage; Trend

\section{Introduction}

In the past, shipbuilding industry of the east enjoyed superiority. But after World War II shipbuilding becomes a European industry in which Britain took the lead [1]. This is followed by Japan (1960s to 1980s). Japan established herself as number one shipbuilding nation by manufacturing oil carriers for the world [2]. Then South Korea took the lead. Presently China possesses the largest shipbuilding industry in the world. Therefore the world shipbuilding market is moving toward east and present global market share has been shown in Table 1. Bangladesh had an excellent history in shipbuilding since ancient. But this sector was disappeared because of technological changes in the world. The modern era of shipbuilding industry started its journey from the western countries. But due to the global impact as the cost of everything went up, the trend of shipbuilding industry was shifted from west to east. Thus the countries like China, Korea, Philippines and Vietnam are dominating the sectors. At present, the countries like Bangladesh, India, Indonesia, Turkey and Brazil are trying to hold the surplus market of shipbuilding industry, especially those demands that are not entertained by the traditional shipbuilding nations. It is an overview paper based on both primary and secondary information and extensive analysis of the fact and history of development of shipbuilding and design technology. In this paper effort will be made to analyze the important factors that steer global leading shipbuilding nation i, e China, Japan and South Korea and lesson learn for Bangladesh as shipbuilding nation.

Table 1: World Shipbuilding market share by countries (2014).

\begin{tabular}{|c|c|c|c|}
\hline Rank & Country & Combined (GT) & Percentage \\
\hline 1 & China & $67,000,000$ & $45 \%$ \\
\hline 2 & South Korea & $53,000,000$ & $29 \%$ \\
\hline 3 & Japan & $28,000,000$ & $18 \%$ \\
\hline 4 & Philippines & $6,000,000$ & $1 \%$ \\
\hline 5 & European Union & $4,500,000$ & $1 \%$ \\
\hline 6 & Rest of the world & $11,000,000$ & $6 \%$ \\
\hline
\end{tabular}

\section{Global Trend of Shipbuilding}

If we analyze the trend of global shipbuilding industry, we found that, Japan had been the dominant ship building country from the 1960s through to the end of 1990s but gradually lost its competitive advantage to the emerging industry in South Korea which had the advantages of much cheaper wages, strong government backing and a cheaper currency. South Korean production overtook Japan's in 2003 and Japanese market share has since fallen sharply. From 2010 China become number 
one shipbuilding nation leaving behind Korea and Japan. The Philippines has placed fourth among shipbuilding nations around the world producing more than six million deadweight tons of ships built in 2012. The country is anchored by South Korean Hanjin and Japan's Tsuneishi shipbuilders. The country has shipyards in Subic and Cebu. The market share of European ship builders began to decline in the 1960s as they lost work to the Japanese in the same way as Japanese builders have lost work to South Koreans more recent past; Europe's production is now a tenth of South Korea's and is primarily military, although cruise liners and some cargo ships are still built in Italy, Finland, France, Germany and Denmark. The largest shares of the European shipbuilding market belong to Germany, Italy, Norway, the Netherlands and Spain, which accounted in 2010 for over $70 \%$ of total deliveries by the yards. This activity accounted in 2010 for $1.5 \%$ of European GDP. Over the four years (2007 to 2010), the total number of employees in the European shipbuilding industry declined from 150,000 to 115,000 . The output of the United States also underwent a similar change and
USA shipbuilding industry decline and $20 \%$ employees loose their jobs.

\section{Analysis of Global Shipbuilding Market Instability} and Protective Measured by Countries

It is clearly obvious from Figure 1 that the change of the new ship demand curve follows the sinusoidal curve; i.e., it is the cyclic with the time. From this graph, it has been seen that at first half cycle phase of the sinusoidal curve the demand was at the trough at 2005 and continued to rise at peak until 2007, finally then fell down at 2009. At the second half cycle phase, the demand was at the peak on 2010 and fell down on 2012. From the last half cycle phase, the demand curve rose again and reached the highest point on 2013, and then it decreased gradually. It is obvious that shipbuilding markets are always unstable; exists between hope and frustration and never remains platitude. This phenomenon is hopeful for ship building market and shipyards and if this trend remains continue, then it is expected that the ship orders/ demand will increase within next few years.

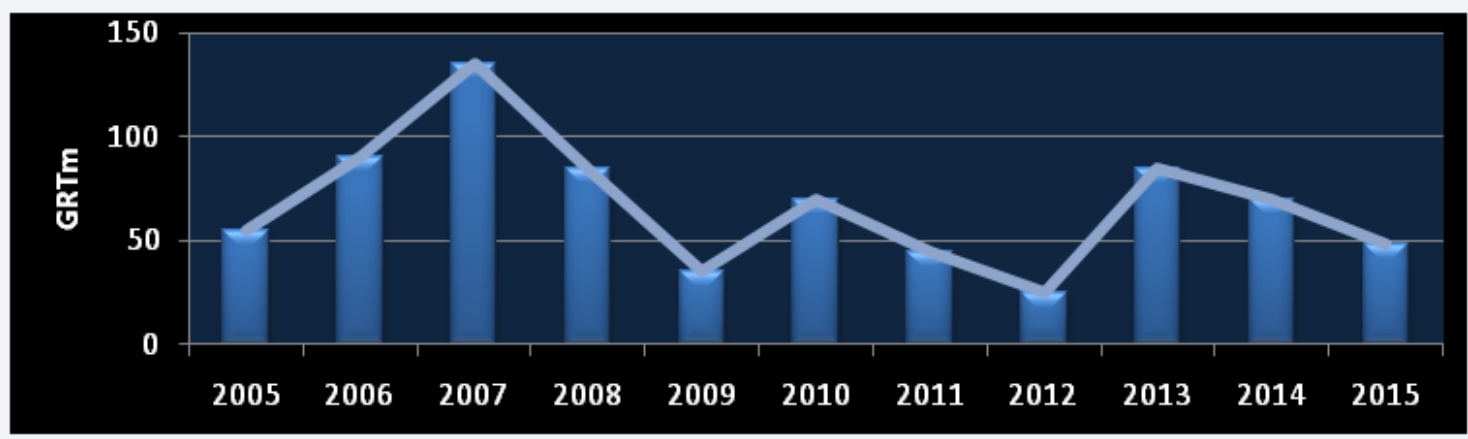

Figure 1: Global new ship order book in million GRT in last decade.

The shipbuilding industry was dealt a huge blow by the global economic crisis in 2008, when vessel demand decreased, dragging down prices and shortening order book covers over the following years. Despite big fluctuations in price and demand, the major markets-China, Japan and South Korea - remain at the forefront of the global shipbuilding and ship repair industry. There are strong reasons behind the growth of their ship building market. Financial backing of their governments, investment by the own countries, a healthy dose of foreign investment due to lower labor costs, scheduled infrastructure developments and business friendly regulations helped them to reach peak position in 2015. Figure 2 shows that ship building investor of the countries like Japan, China, Singapore, United States, South Korea, etc invest in their domestic sectors and boast up their industry and help them to survive in the global market.

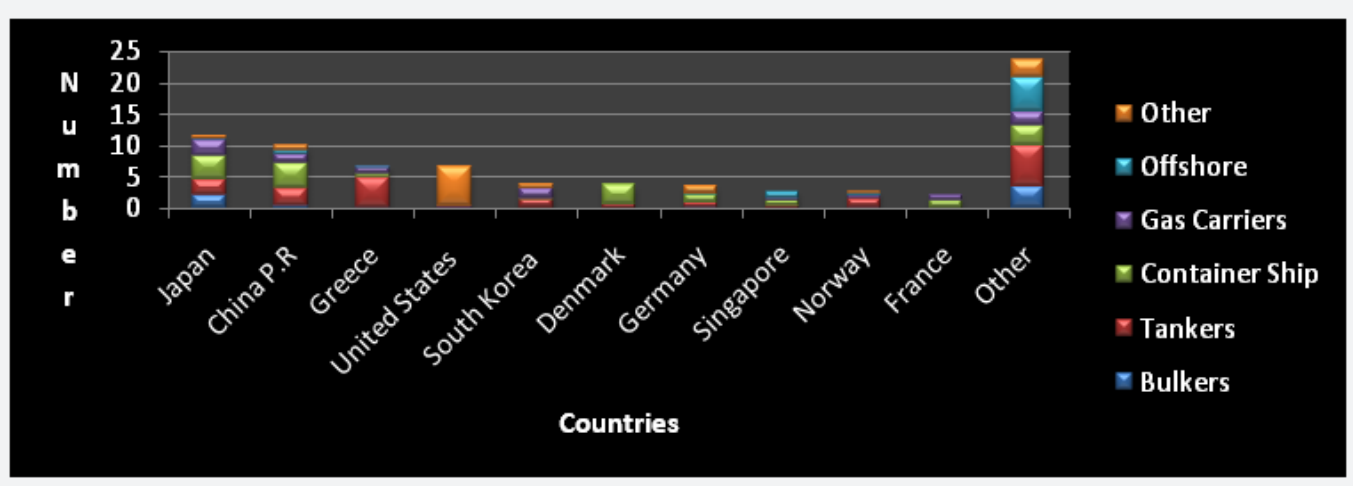

Figure 2: Investment by the countries in their own shipbuilding industry as protective measure. 


\section{Shipbuilding Practice in Modern Days}

Conventional shipbuilding was labor intensive and lowtech industry [3]. On the other hand modern shipbuilding is lot of automation and line production manufacturing skilled workforce. Modern shipbuilding makes considerable use of prefabricated sections. Entire multi-deck segments of the hull or superstructure will be built elsewhere in the yard, transported to the building dock or slipway, then lifted into place. This is known as «block construction». The most modern shipyards pre-install equipment, pipes, electrical cables, and any other components within the blocks, to minimize the effort needed to assemble or install components deep within the hull once it is welded together. Ship design work, also called naval architecture produced almost exclusively of welded some ships suffering catastrophic brittle fracture structural cracks. Since roughly 1950, specialized steels such as high tensile strength and tough steel with good physical and chemical properties for ship construction have been used. Although it is commonly accepted that modern steel has eliminated brittle fracture in ships [4]. Distinct beautification and work fineness found in modern shipbuilding.

\section{Specialized Technology and Skilled Labor Boast up Shipbuilding}

In the 1950s, the shipbuilding industry of Japan was comparatively lagging behind once leading shipbuilding nations in Europe and America. It was really a astonish when Japanese engineers visited the shipyards in USA, since many sophisticated production methods, such as block building and welding, had been employed for years [5]. In this relation, the works of catching up was the first thing for the shipbuilders to do. Not surprisingly, the catching-up did not take long time. After mastering existing shipbuilding technologies learned from the leading shipbuilding nation, the shipbuilders in Japan began to develop by its own knowledge and expertise. Japanese Shipyards started to improve the layout of the plants and facilities in order to improve efficiency on building large blocks for large ships. The shipyards actively took part in the programs raised by Shipbuilding Rationalization Council and they improve the welding rods and steel plates. Again Japanese Shipyards develop idea "how to build" instead of "what to build" philosophy unlike other countries. This new philosophy in Japan integrated all working processes into general working plan and all processes were planned in advance. Evidence shows that major improvement in productivity during the 3-year-period (from 1953 to 1956), the man-hour required for building a 50,000 DWT tanker was reduced by $20 \%$, besides, the consumption in steel for the same ship decreased by $20 \%$. This strongly implies the competitiveness of industry to meet the demands from ship owners for earlier delivery as well as cheaper cost of new ships. Finally, new philosophy increased the efficiency and the productivity of the Japanese shipyards and ultimately Japan became No.1 shipbuilding nation in the world in 1956. Again, economic class ship invented by Japan, which was the outcome of trans-normal wisdoms generated by the participants and was considered as a paradigm shift in that era. It minimized the cost of building really large ships and proved to be most economical form of transport bulk cargoes. This had a direct influence in reducing the expenditures in both construction and operations.

\section{Technical Innovation and Managerial Skill Promote Shipbuilding}

The trustworthy efforts on innovation combining with new technology and skilled management are the approach to secure long-term prosperity of the industry. Korean shipbuilders have a strong capability of developing own ship models [6]. The Korean shipbuilders took years to develop designs and building technologies for large container ships and larger LNG carriers. And in 2004, Korean shipyards get 57 ships out of total orders of 86 LNG tankers in the world. When looking into the size of carriers they built, the average size of the carriers was 72,860 GT per unit that suggests the largest LNG carriers are under construction in Korea. Moreover, in the larger containership sector, Korean shipbuilders were the only dominator on the global market, the strengths of grasping orders of new buildings not only derive from the design and building technologies but also from advanced shipyard management, because building such large ships in fairly high speed requires unusual manufacturing flows as well as skillful supply chains. In addition, the number of ship designers could certify the strong ability on the aspect of ship design. In Korea, some 2000 sophisticated ship designers actively work for the industry, adversely, in Japan; the numbers of designers is only 200. Additionally, every year there are about 700 young professionals in relation to shipbuilding graduated from universities in Korea, which guarantees sustainable development of the industry. Korean shipbuilders shared the views with their Japanese counterparts that the efficiency of the shipbuilding does come from the improvement of productivity. Traditional production technology always has it limits so that innovation in building technology is vital to improve productivity. In order to obtain efficiency in the building of LNG carriers, Hyundai Heavy Industry (HHI) spent 3 years indulging itself in the field of ship design and building technology. In1999, HHI largely shortened the construction period of a LNG tanker in 130,000 cubic meters to only 109 days. Thus, the international competitiveness was considerably established for this particular ship type. Another famous shipbuilder Daewoo innovated the method of better utilization of docks, through perfect and precise organization and management, this shipbuilder was able to build several vessels in different types within one dock, thus greatly improved the efficiency. Some shipyards in Korea even introduced the production concept of car manufacturing into the shipbuilding; it was the case of Samsung Heavy Industry, as such the productivity was improved. In the years of 2004, due to very strong demand of new buildings worldwide, with aim to accommodate more orders, HHI used dry-land facilities, which was the building technology of offshore construction, to build and deliver 16 Aframax to the market [7] (Figure 3). 

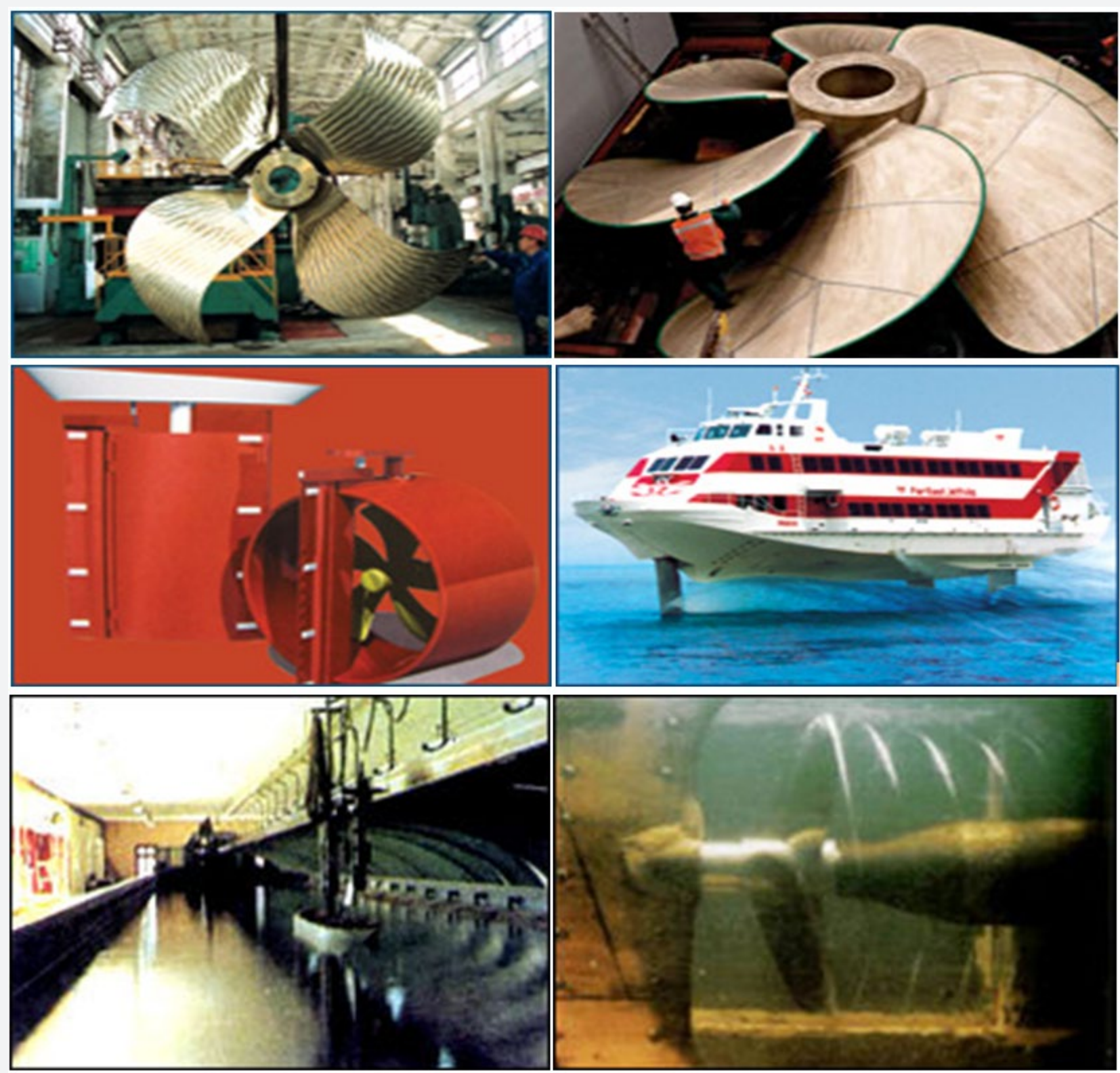

Figure 3: Few Images of R\&D activities and its' output in global shipbuilding (Marine Propeller; Rudder; High Speed Hydrofoil; Towing Tank and propeller Wake).

Industrialization is the Precondition for Development of National Shipbuilding

Since 1955, the takeoff of Japanese economy created much import and export. As a result, economic environment provided excellent opportunity to grow domestic shipping industry, consequently the shipbuilding industry. In a 10 -year period, import increased from 2,400 millions US dollars to 7900 millions, a rise of $330 \%$. The commodities imported by Japan were raw materials and energy, such as iron ores and crude oil. Export performed at almost the same growth rate which raised from 2000 millions US dollar to 6600 millions US dollars. During the period, the structure of the Japanese economy experienced a change from mainly producing the commodities of light industry to producing the products of heavy industry. Huge amount of import and export required a big fleet to support. Therefore, the Japanese shipping industry responded to the demands by increasing the tonnages from 3735000 GT to 10813000 GT. On the other hand, the industrialization of South Korea started in early 1970s. The economy showed the same distinctiveness as the Japanese economy did in the middle of 1950s. South Korea started to import huge amount of raw materials and energy and export many products of heavy industry. During the process of the industrialization in the country, the shipbuilding industry developed due to huge internal demand for the ships as well [8] (Figure 4). 


\section{Recent Advances in Petrochemical Science}

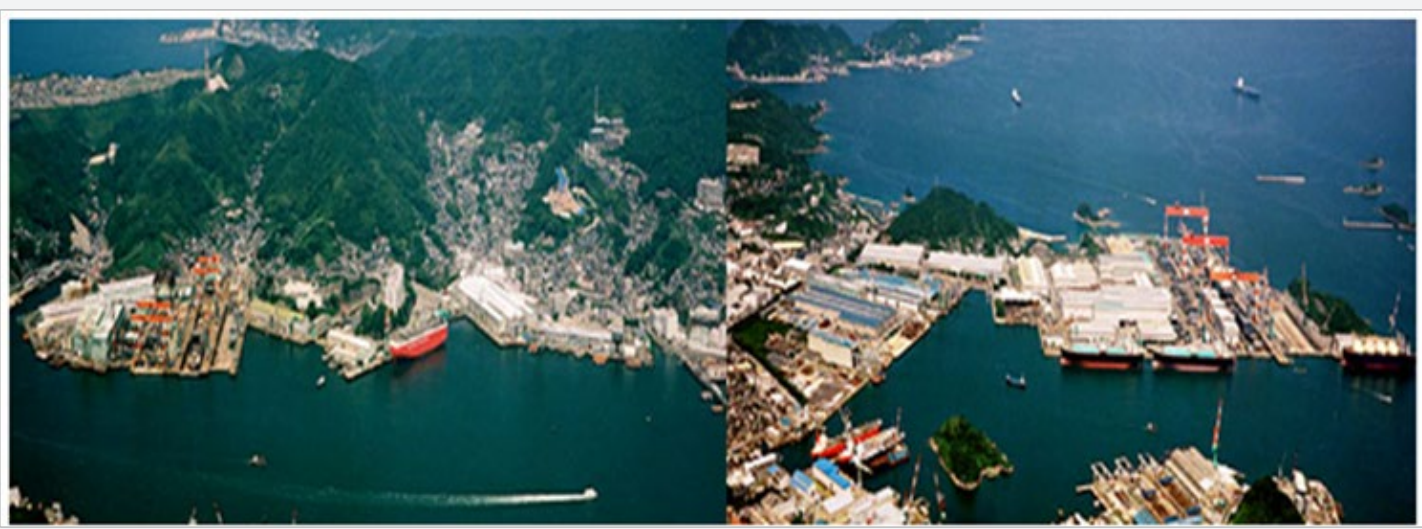

Figure 4: Nagasaki kayaji and kouyagi shipyards in Japan.

Financial Support and Involvement of Government is the Main Driving Force to Grown up Shipbuilding

As early 1950s, the Japanese governmentlaunched a "Program Shipbuilding Scheme", which allowed the Japanese shipping companies to obtain favorable loans for fleet expansions. The scheme ruled the shipping companies who received the loads out of public money should only build the ships in Japan. Still today, the said scheme is remain alive. Moreover, in order to attract ships' orders of new buildings on the international market for the Japanese shipbuilders, the government provides low-interest loans to foreign ship owning companies through export and import bank of Japan. Again realizing the Japanese shipbuilding Industry was not competitive in the international market in 1950s, the government set up Shipbuilding Rationalization Council for the shipbuilders. The council consisted of maritime experts from all fields related to the shipbuilding aiming to improve overall competences of the shipbuilders. For instance, at that moment, the prices of steel in Japan were 30\% higher than the prices in other shipbuilding nations, so the council was asked to work with domestic steel manufacturers to resolve the problem. In order to fulfill this goal, the government decided to offer financial aids to steel works. It was the famous "interest subsidy". Meanwhile, the government also provided licenses with steel works for trading urgent commodities for the nation; the profits out of these trades must pay for the expenses of $\mathrm{R}$ \& D for the steel plates for ship use. Finally, the prices of steel decreased and the quality of steel improved. Furthermore, the officials also actively initiated and involved in reorganization and co-operation among Japanese shipbuilders by offering viable policies and funds to the industry. On the other hand, in terms of financial aids, the measures taken by the Korean government are quite similar to the Japanese government. In 1957, Export and Import Bank of Korea was set up to facilitate the shipbuilding industry. Currently, the portfolio size of the Bank is one of the largest sources for ship financing in the world. In 1967, the enactment of Shipbuilding Industry Promotion Act lined the way for the shipbuilding industry. Since then, the industry has received tremendous support from the government. Again in 2004 , the Korean government limited the quantity of steel plates to export for the shipbuilders in China due to scarcity in steels for the shipbuilding worldwide [9] (Figure 5).

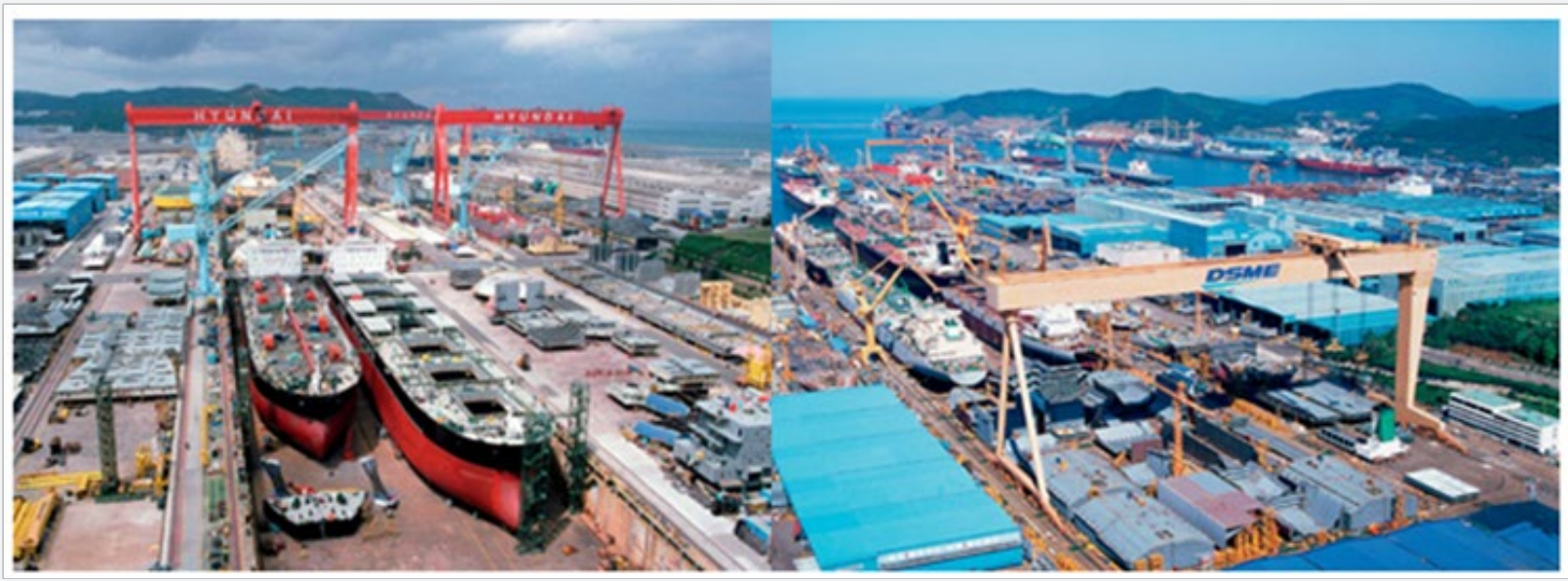

Figure 5: Hyundai heavy industries and Daewoo shipyards in South Korea. 


\section{Recent Advances in Petrochemical Science}

Co-Operation among Local Shipyards is the Most Significant Issue to Improvement of National Shipbuilding Industry

The success of the Japanese shipbuilding industry can also be attributed to reorganization of industrial structure along the development and constant co-operation among the shipbuilders. This increased the competitiveness of the industry as a whole. The merger or joining activities of major shipbuilders in Japan principally focused on enhancement of financial status and improvement on efficiency through better utilization of building facilities as well as human resources. In other words, the mergers provided the opportunities for the builders to avoid duplicated investments in capacity. After several mergers, seven large shipbuilding groups emerged in Japan. They mainly targeted at the market of larger ships, such as VLCCs etc, as Backward Linkage and Supply Chain is the Important Prerequisite to Enhancement of Shipbuilding well as higher value markets. Co-operation between smaller shipyards and large ones was the outcome of government policy of Japan in 1964 and both sides benefited from it with smaller one happily obtaining the know-how from larger ones and larger ones rationally allocated mid-size or smaller ships to smaller ones from the bale orders received at the shipbuilding market. On the other hand, the co-operation among the shipbuilders in South Korea is realized through several organizations. The Large shipbuilders, 5 mega-shipyards, established Korean Shipbuilder's Association in 1977 (Koshipa). The major functions of the association are to co-ordinate the interests on the international market facilitate technological exchanges and enhance international partnerships. So the co-operation among the shipbuilders is the key to lift up the overall capability of the industry [10].

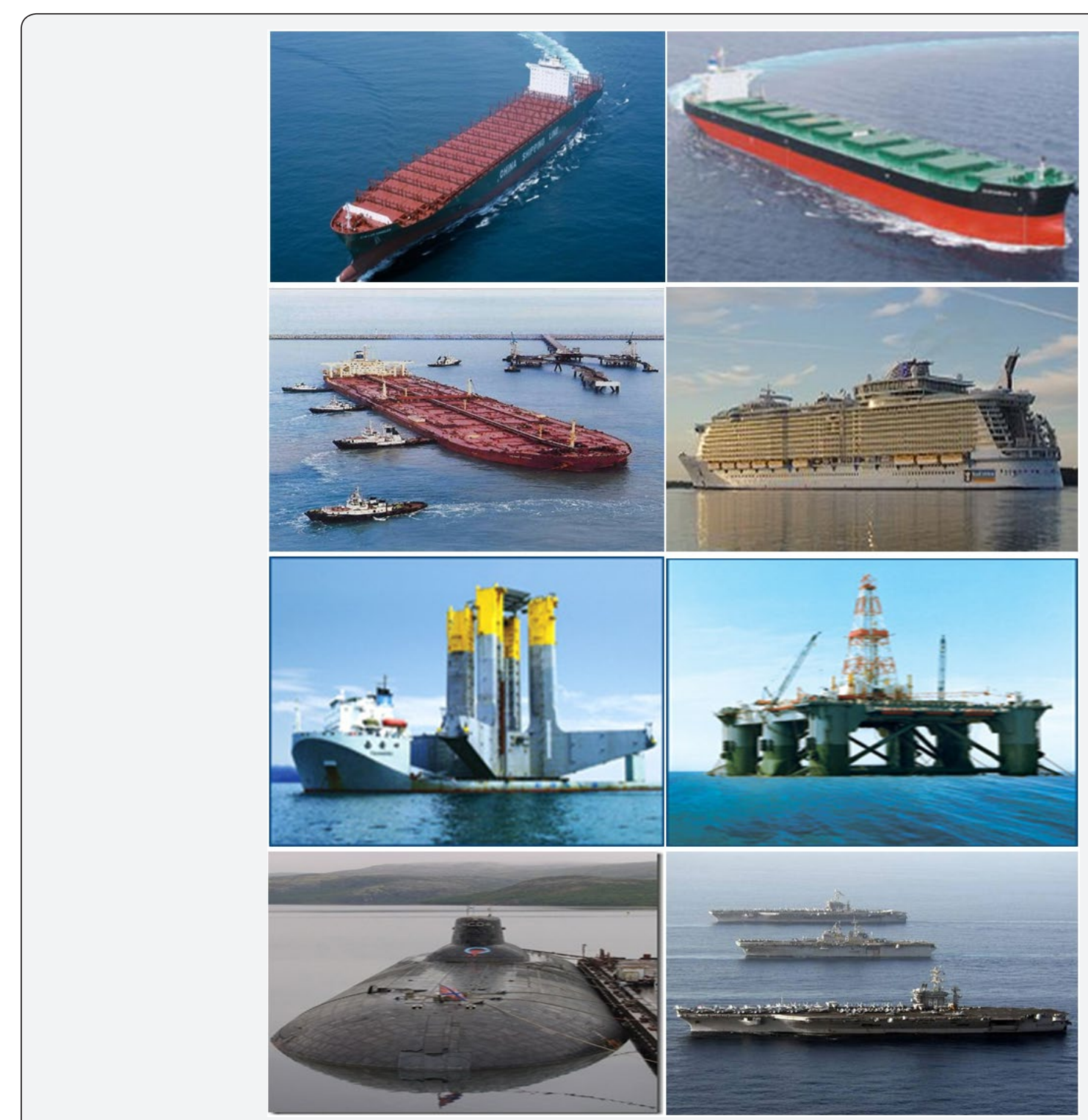

Figure 6: Product of Global Leading Shipyards (Largest Supper Tanker; Passenger Ship; Container Carrier; Bulk Carrier; Semi-Submersible Heavy Vessel; Semi-Submersible Drilling; Nuclear Submarine; Nuclear Aircraft Carrier). 
The success of the Japanese shipbuilding industry is largely based on the capability of the backward linkage industries or supply chain to the industry. In Japan, the shipbuilders can easily find everything they need for the new buildings. Domestic suppliers such as the engine manufacturers and the steel works provide excellent prices and services to the shipbuilders, For instance, steels works supply the steels to the shipbuilders with various sizes and shapes in according with the requirements as per the drawings of the shipbuilders. Such service is hard to image in other shipbuilding nations. The co-operation in the supply chain inevitably leads to efficiency and finally the international competitiveness. Moreover, the communication between the shipbuilders and the suppliers is very effective, both parties benefit from respective performances. So far, the rate of domestic supplies for the new buildings in Japan has reached to $97.8 \%$. On the other hand, in South Korea the rate of domestic availability for the supplies is about $85 \%$. Major suppliers in Korea belong to Korean Marine Equipment Association. The association aims at a higher rate of supplies for the shipbuilding industry in Korea. At present, the shipyard is mostly an assembly plant, which relies on the capabilities of the entire backward linkage industries or supply chains (Figure 6).

\section{Story Behind to Become China as no 1 Shipbuilding Nation in the Globe}

China is investing heavily in all aspects of the industry, with the purpose of lifting China to become the largest economic and maritime power in the world within 2020. Shipbuilding industry has greatly contributed to industries such as water transportation, fishery and marine development since China joined WTO in 2001. Shipbuilding industry is developing speedily in China. As with other industries, China begins by emphasizing its low labor rates and then moves up the value chain to highertechnology (higher-value) products (i.e., more sophisticated ships). Government policy, national maritime strategy and other supportive measure help the local shipyards to survive and flourish in the global market. Status of the all industry in Chinese economy keeps rising since last three decades. Now China is the largest industrial nation leaving USA behind marginally. As shipbuilding nation China is also number one in the world leaving behind South Korea and Japan. The completion volume of ships in China has been increasing rapidly since the 1990s, making China one of the shipbuilding centers in the world. The number of new ship orders in China amounted to around 50\% of the global new orders in 2014, which was top of the world for five consecutive years. Delivery amount of new ships in China.

\section{Conclusion}

Shipbuilding is an important and strategic industry, because it has one of the highest multiplier effects among all other industries. Britain upto WW I, USA upto WW II, Japan after WW II, South Korea upto 2010 and China at present leading the global shipbuilding industry and enrich their other SMEs and backward linkage industries. Technical innovation and managerial skill always promote shipbuilding. During the process of the industrialization in the country, the shipbuilding industry developed due to huge internal demand for the ships as well. Financial support and involvement of government is the main driving force to grown up shipbuilding. Again, the co-operation among the shipbuilders is the key to lift up the overall capability of the industry. The success of the Chinese and Japanese shipbuilding industry is largely based on the capability of the backward linkage industries or supply chain to the industry. Shipbuilding is therefore an attractive industry for developing nations. Shipbuilding industry of Bangladesh has all the potentials to flourish and penetrate the global markets if Bangladesh learns the lesson as discuss above.

\section{References}

1. McCarthy M (2005) Ship's Fastenings: from sewn boat to steamship. In: ( $1^{\text {st }}$ edn), Texas A\&M Press. College Station, USA, p. 229.

2. Jaffee, Walter CW (1997) The Lane Victory: The Last Victory Ship in War and Peace. In: ( $2^{\text {nd }}$ edn), Glencannon Press, Palo Alto, USA.

3. Sawyer LA, Mitchell WH (1985) The Liberty Ships: The History of the "Emergency" Type Cargo Ships Constructed in the United States During the Second World War. In: ( $\left.2^{\text {nd }} e d n\right)$, Lloyd's of London Press Ltd., London, England, UK.

4. Drouin P (2006) Brittle Fracture in ships-a lingering problem. Ships and Offshore Structures 1(3): 229-233.

5. Herman A (2012) Freedom's Forge: How American Business Produced Victory in World War II. Random House, New York, USA.

6. Brooke J (2009) Korea reigns in shipbuilding, for now. The New York Times, New York, USA.

7. (2014) China Will Be World's Largest Economy In 2024: HIS Economics.

8. https://www.bharatbook.com/marine-and-shipping-marketresearch-reports-354707

9. http://en.qianzhan.com/report/detail/3c9944de618e465f.html

10. http://www.ibisworld.com/industry/china/ship-building.html 
(C) This work is licensed under Creative

BY DOI: 10.19080/RAPSCI.2018.04.555650

\section{Your next submission with Juniper Publishers} will reach you the below assets

- Quality Editorial service

- Swift Peer Review

- Reprints availability

- E-prints Service

- Manuscript Podcast for convenient understanding

- Global attainment for your research

- Manuscript accessibility in different formats

( Pdf, E-pub, Full Text, Audio)

- Unceasing customer service

Track the below URL for one-step submission https://juniperpublishers.com/online-submission.php 